\title{
Interferensi Leksikal Bahasa Arab dalam Bahasa Indonesia di Lingkungan Pondok Pesantren Riyadhul Huda Kota Tangerang
}

\author{
Imamudin $^{1}$, Haerudin ${ }^{2}$ \\ Universitas Muhamamdiyah Tangerang \\ imamudinalzainy@gmail.com
}

\begin{abstract}
Abstrak
Penelitian ini bertujuan untuk mendeskripsikan bentuk interferensi leksikal bahasa Arab dalam bahasa Indonesia di Lingkungan Pondok Pesantren Riyadhul Huda Kota Tangerang. Pendekatan yang digunakan dalam penelitian ini adalah pendekatan kualitatif dengan metode analisis deskriptif. Hasil penelitian ini menunjukan bahwa bentuk interferensi leksikal yang terdapat dalam penelitian ini berupa interferensi leksikal pada beberapa kelas kata dasar dan turunanannya. Bentuk interferensi terjadi pada kelas kata benda (nomina), kelas kata kerja (verba), kelas kata sifat (adjektiva), kelas kata pengganti (pronominal), kelas kata bilangan (numeralia), kelas kata keterangan (adverbia) dan kelas kata tugas. Jumlah interferensi leksikal dari hasil wawancara dialog santri yaitu sebanyak 57 kata, dengan interferensi paling banyak yaitu pada kelas kata kerja (verba).

Kata kunci: Interferensi, Leksikal, Bahasa Arab

\section{A. Pendahuluan}

Indonesia merupakan negara yang ditempati oleh masyarakat yang majemuk. Berbagai macam suku dan etnis ada di Indonesia. Antara lain adalah suku Aceh, Batak, Melayu, Betawi, Sunda, Jawa, Madura, dan lainnya. Seiring dengan banyaknya suku di Indonesia, maka banyak pula macam bahasa yang ada di Indonesia. Hal ini menyebabkan negara Indonesia kaya akan bahasa. Bahasa merupakan alat komunikasi yang digunakan oleh individu atau anggota masyarakat tertentu untuk menyampaikan gagasan, pikiran berdasarkan bahasa yang digunakan di tempat mereka tinggal. Dalam kesehariannya tentunya setiap anggota masyarakat melakukan komunikasi agar dapat menjalin hubungan yang baik antar anggota masyarakat. Oleh karena itu, tak ada seorang pun yang luput dari kegiatan berkomunikasi dalam kehidupan bermasyarakatnya. Hal ini menandakan bahwa bahasa sangat diperlukan bahkan amat penting bagi setiap individu.
\end{abstract}


Sebagaimana kita ketahui, pondok pesantren merupakan lembaga pendidikan khas Indonesia. Jika India memiliki gurukula atau Pakistan dan Bangladesh mempunyai madrasah. Umat Islam di Indonesia punya pesantren, karena cita rasa Indonesia, maka pesantren menjadi sebuah lembaga pendidikan yang memiliki keterikatan dan keterkaitan historis dengan sejarah perkembangan Islam di Indonesia sejak abad kehidupan para wali hingga saat ini. Pondok pesantren adalah saksi dan pelaku sejarah bagi perjuangan serta jatuh bangunnya persada bumi nusantara mengukuhkan eksistensi kenegaraan dan kebangsaannya.

Tatkala Indonesia memasuki abad baru, millenium baru dalam tatanan peradaban sains dan teknologi, maka program pendidikan yang digunakan oleh pondok pesantren kian memiliki banyak perubahan. Pondok pesantren yang awalnya hanya mengkaji kitab-kitab klasik (kitab kuning) lambat laun memasukan program-program lain seperti menggunakan bahasa asing dalam berkomunikasi sehari-hari. Bahasa asing yang biasa digunakan dalam pondok pesantren adalah bahasa Arab dan bahasa Inggris. Program seperti ini biasanya lebih banyak diadopsi oleh pondok-pondok pesantren yang berbasis modern walaupun ada juga yang digunakan atau diadopsi oleh pondok pesantren yang berbasis salaf.

Interferensi adalah penyimpangan norma bahasa yang membuat elemen suatu bahasa menjadi seperti elemen bahasa lain. Semakin besar sistem bahasa ibu dengan bahasa lain, maka semakin besar pula masalah yang dihadapi oleh seseorang dalam mempelajari bahasa tersebut, karenanya semakin besar pula potensi terjadinya interferensi. Hal ini diakibatkan karena dalam proses belajar bahasa asing (B2), seseorang cenderung mentransfer ungkapan dan makna bahasa ibu (B1), serta hubungan antara keduanya pada bahasa asing yang sedang dipelajarinya.

Oleh karena dilatarbelakangi perbedaan sistem leksikon antara bahasa Indonesia dengan bahasa arab, para santri mengalami kesulitan dalam mempelajari dan menyusun gramatikal bahasa arab yang kemudian diucapkan sebagai bahasa sehari-hari di dalam pondok pesantren. Berangkat dari perbedaan dalam kedua sistem leksikon bahasa itu, maka penulis mengangkat judul penelitian "Interferensi Leksikal Bahasa Arab dalam Bahasa Indonesia di 
Lingkungan Pondok Pesantren Riyadhul Huda Kota Tangerang” Tujuan dari penelitian yang dilakukan oleh penulis ini yaitu 1) mendeskripsikan terjadinya interferensi leksikal bahasa Arab yang terjadi di lingkungan pondok pesantren ketika para santri berkomunikasi dengan menggunakan bahasa Indonesia; 2) mengetahui bentuk interferensi leksikal yang paling dominan muncul dalam tuturan bahasa Indonesia para santri Riyadhul Huda.

\section{B. Kajian Pustaka}

Weinreich (1953) sebagai ahli yang pertama kali menggunakan istilah interferensi mendefinisikan bahwa yang dimaksud dengan interferensi adalah perubahan sistem suatu bahasa sehubungan dengan adanya persentuhan bahasa tersebut dengan unsur-unsur bahasa lain yang dilakukan oleh penutur yang bilingual (dalam Chaer \& Agustina, 2010, h.120). Maksud dari pendapat yang diungkapkan oleh Weinreich, peneliti memahami bahwa interferensi merupakan penyimpangan bahasa akibat penggunaan dua bahasa oleh penutur sehingga merubah sistem bahasa ibu (B1) dengan masuknya unsur-unsur bahasa asing (B2).

Sedangkan Mulyono (2016) membatasi bahwa interferensi merupakan masuknya unsur bahasa lain terhadap bahasa tertentu yang bersifat melanggar kaidah bahasa, yang menyerap dan pencampurbauran pola bahasa (h.31). Interferensi merupakan rusaknya kaidah bahasa sebab bercampurya unsur bahasa tersebut dengan unsur-unsur bahasa lain.

Berbicara mengenai interferensi tak luput dari integrasi karena keduanya memiliki pengertian yang sama, yaitu peristiwa pemakaian unsur bahasa yang satu ke dalam unsur bahasa lain yang terjadi dalam diri penutur. Namun keduanya perlu dibedakan karena interferensi dianggap sebagai gejala tutur yang terjadi hanya pada dwibahasawan dan peristiwanya dianggap sebagai penyimpangan, sedangkan integrasi cenderung sebagai gejala bahasa yang dapat terjadi pada setiap anggota masyarakat dan peristiwanya bukan lagi sebagai penyimpangan karena sudah menyatu dan diterima oleh masyarakat (Aslinda dan Syafyahya, $h$. $65)$.

Secara etimologi kata leksikologi diturunkan dari kata leksem yang terlebih dahulu menurunkan kata leksikon dan bentuk adjektivanya leksikal. Istilah leksikon lazim digunakan untuk mewadahi konsep "kumpulan leksem" dari satu 
bahasa, baik kumpulan secara keseluruhan maupun secara sebagian. Dalam peristilahan sekarang mungkin istilah leksikon ini bisa disepadankan dengan istilah kosa kata yang sudah amat lazim digunakan dalam pemelajaran bahasa. Kata leksikon yang berstatus nomina, memiliki adjetivanya yang juga sudah lazim digunakan yaitu leksikal, dalam arti bersifat leksikon.

Sebagaimana dibahas diatas bahwa lesikal atau leksikon merupakan istilah dalam ilmu linguistik yang berarti perbendaharaan kata. Setiap bahasa memiliki perbendaharaan kata yang cukup banyak, bahkan puluhan tibu kata. Unsur leksikal merupakan unit dan struktur bahasa yang bersifat terbuka sehingga mudah berubah, mudah dipengaruhi, dan mudah pula menerima tambahan pengaruh dari luar. Pengaruh berupa interferensi leksikal merupakan gejala umum yang sering terjadi dalam kontak bahasa. Hampir tidak ada bahasa yang bebas sepenuhnya dari interferensi ini.

Menurut Aslinda dan Syafyahya (2014), interferensi dalam bidang leksikal terjadi apabila seorang dwibahasawan dalam peristiwa tutur memasukan leksikal bahasa pertama ke dalam bahasa kedua atau sebaliknya (h.73). Menurut pemahaman peneliti dari apa yang diungkapkan oleh ahli di atas adalah bahwa interferensi leksikal itu berarti penggunaan kosakata 2 bahasa dalam peristiwa tutur yang menyebabkan tercampurnya kosakata bahasa pertama dengan kosakata bahasa kedua.

\section{Metodologi Penelitian}

Penelitian pada dasarnya merupakan suatu pencarian, menghimpun data, mengadakan pengukuran, analisis, sintesis, membandingkan, mencari hubungan, menafsirkan hal-hal yang bersifat teka-teki. Banyak jenis pencarian yang dapat dilakukan, salah satunya yaitu berdasarkan pendekatan. Pendekatan yang digunakan dalam penelitian ini adalah pendekatan kualitatif.Sumber data yang terkait dengan penelitian ini adalah dialog santri di Pondok Pesantren Riyadhul Huda Kota Tangerang. Data primer dalam penelitian ini adalah dialog santri Pondok Pesantren Riyadhul Huda Kota Tangerang yang berjumlah 50 santri. Data sekunder juga dapat berupa buku-buku referensi yang dijadikan acuan dalam penulisan penelitian ini. Data sekunder dalam penelitian ini adalah buku referensi yang terkait dengan objek penelitian. 
Teknik pengumpulan data yang dilakukan oleh peneliti adalah dengan cara: 1) observasi yang dilakukan oleh peneliti di Pondok Pesantren Riyadhul Huda Kota Tangerang dengan jumlah santri 50 orang. Metode observasi dalam penelitian bahasa dikenal sebagai metode simak. Untuk menjalankan teknik simak ini, peneliti hanya menjadi pengamat atau penyimak. Untuk melengkapi teknik ini peneliti menggunakan teknik lanjutan berupa teknik rekam, dengan teknik ini peneliti merekam menggunakan alat rekam yang disediakan oleh peneliti sendiri. Selain itu, teknik catat merupakan pelengkap teknik rekam jika didapat suatu percakapan yang tidak memungkinkan direkam. Metode ini dipakai karena tepat untuk mengambil data bahasa yang berupa dialog. Sedangkan teknik rekam dengan menggunakan tape recorder atau handphone untuk mendokumentasikan data bahasa dalam bentuk dialog; 2) Teknik wawancara mendalam ini digunakan oleh peneliti untuk menggali dan mengumpulkan data yang berhubungan dengan interferensi bahasa Arab di pondok pesantren Riyadhul Huda. Sebagai informannya adalah beberapa santri (5-10 santri) sebagai sample yang dipilih untuk memberikan informasi secara utuh dan menyeluruh tentang permasalahan yang sedang diteliti.

Analisis data yang digunakan dalam penelitian ini adalah analisis deskriptif. Analisis deskriptif ini digunakan peneliti untuk mencari data interferensi leksikal yang terdapat dalam dialog santri Riyadhul Huda. Aktivitas dalam menganalisis data dilakukan dengan tiga tahap yaitu, reduksi data, penyajian data, dan menarik simpulan. Pada tahap reduksi data,d ata yang dipilih hanya data yang berkaitan dengan masalah yang dianalisis. Dalam hal ini adalah interferensi leksikal pada dialog santri Riyadhul Huda. Selanjutnya penyajian data yaitu peneliti mengelompokan hal-hal yang serupa menjadi kategori kelompok satu, kelompok dua, kelompok tiga, dan seterusnya, sehingga diperoleh jenis interferensi leksikal pada dialog santri Riyadhul Huda. Langkah terakhir yaitu menarik Simpulan yakni berdasarkan data-data yang telah diperoleh dari dialog santri Riyadhul Huda. Kesimpulan awal yang dikemukakan masih bersifat sementara dan akan berubah bila tidak ditemukan bukti-bukti yang kuat dan mendukung pada tahap pengumpulan data berikutnya.

\section{Pembahasan}


Berdasarkan dari hasil temuan dalam penelitian ini, peneliti akan membahas interferensi leksikal bahasa arab yang terjadi pada tuturan santri Riyadlul Huda ketika berkomunikasi antar santri. Berikut ini penjelasan interferensi yang terjadi :

\section{Interferensi kata Kaif}

Kata kaif merupakan kata bahasa arab yang menunjukan kata tanya untuk sebuah keadaan. Kata kaif sebagaimana dalam kamus bahasa arab Mahmud Yunus ditulis كَيْهَ (kaifa) yang berarti 'bagaimana'. Kata bagaimana merupakan kosakata yang termasuk ke dalam kata ganti penanya (pronomina penanya). Kata ganti penanya (pronomina penanya) memiliki makna menggantikan sesuatu yang ditanyakan. Kata bagaimana termasuk ke dalam kata ganti (pronomina) sebab kata bagaimana menggantikan nomina yang ada yaitu keadaan. Kata kaifa mengalami interferensi, yaitu interferensi leksikal kelas kata pronomina. Interferensi leksikal kelas kata pronomina adalah interferensi yang terjadi karena adanya pengacauan kata ganti (pronomina) bahasa Indonesia oleh bahasa Arab baik dalam bentuk dasar maupun bentuk turunannya.

Contoh kutipan yang terdapat interferensi bahasa arab kaif sebagai berikut :

\section{Ded, kaif kabar ente?}

Kalimat tersebut merupakan struktur kalimat bahasa Indonesia yang mengalami interferensi leksikal bahasa Arab karena terdapat unsur kosakata bahasa Arab yang masuk ke dalam struktur kalimat tersebut. Kosakata yang mengalami interferensi adalah kata kaifa yang seharusnya dalam bahasa Indonesia sudah ada padanan katanya yaitu bagaimana. Kata kaifa sering dipergunakan oleh kebanyakan santri terlebih bagi pesantren yang berbasis modern dalam menyebut kata bagaimana dalam kegiatan percakapan sehari-hari sehingga faktor kebiasaan pun menyebabkan hal tersebut terbawa dalam percakapan sehari-hari.

\section{Interferensi Kata Ente}

Kata ente merupakan kata bahasa arab yang menunjukkan kata ganti (dalam bahasa arab dikenal dengan istilah dhomir ) untuk orang kedua (kamu). Kata ente sebagaimana dalam kamus bahasa arab Mahmud Yunus ditulis (anta) yang berarti kamu. Kata kamu merupakan kosakata yang termasuk ke 
dalam kata ganti persona (pronomina persona). Kata ganti persona (pronomina persona) berarti pronomina yang mengacu kepada orang. Kata kamu termasuk ke dalam kata ganti (pronomina) sebab kata kamu menggantikan nomina yang ada yaitu orang kedua. Kata ente mengalami interferensi yaitu interferensi leksikal kelas kata pronomina. Interferensi leksikal kelas kata pronomina adalah interferensi yang terjadi karena adanya pengacauan kata ganti (pronomina) bahasa Indonesia oleh bahasa Arab baik dalam bentuk dasar maupun bentuk turunannya.

Contoh kutipan yang terdapat interferensi bahasa arab ente sebagai berikut :

Ded, bagaimana kabar ente?

Kalimat tersebut merupakan struktur kalimat bahasa Indonesia yang mengalami interferensi leksikal bahasa Arab karena terdapat unsur kosakata bahasa Arab yang masuk kedalam struktur kalimat tersebut. Kosakata yang mengalami interferensi adalah kata ente yang seharusnya dalam bahasa Indonesia sudah ada padanan katanya yaitu kamu. Kata ente sering digunakan oleh kebanyakan santri untuk menyebut kata kamu dalam kegiatan percakapan seharihari sehingga faktor kebiasaan pun menyebabkan hal tersebut terbawa dalam percakapan sehari-hari.

\section{Interferensi Kata Khoir}

Kata khoir merupakan kata bahasa arab, dalam kamus bahasa arab Mahmud Yunus ditulis خَيْر (khoirun) yang berarti 'baik/ kebaikan'. Kata baik merupakan kosakata yang termasuk ke dalam kata sifat (adjektifa). Kata sifat (adjektifa) berarti kata yang memberikan sifat khusus, watak, atau keadaan yang disebutkan terlebih dahulu . Kata baik termasuk ke dalam kata sifat (adjektifa) sebab kata baik menunjukkan sebuah keadaan yang baik. Kata khoir mengalami interferensi yaitu interferensi leksikal kelas kata adjektifa. Interferensi leksikal kelas kata adjektifa adalah interferensi yang terjadi karena adanya pengacauan kata sifat (adjektifa) bahasa Indonesia oleh bahasa Arab baik dalam bentuk dasar maupun bentuk turunannya.

Contoh kutipan yang terdapat interferensi bahasa arab khoir sebagai berikut :

\section{Ana khoir Bi}


Kalimat tersebut merupakan struktur kalimat bahasa Indonesia yang mengalami interferensi leksikal bahasa Arab karena terdapat unsur kosakata bahasa Arab yang masuk kedalam struktur kalimat tersebut. Kosakata yang mengalami interferensi adalah kata khoir yang seharusnya dalam bahasa Indonesia sudah ada padanan katanya yaitu baik. Kata khoir sering digunakan oleh kebanyakan santri untuk menyebut kata baik dalam kegiatan percakapan seharihari sehingga faktor kebiasaan pun menyebabkan hal tersebut terbawa dalam percakapan sehari-hari.

\section{Interferensi Kata Ta'allum}

Kata ta'allum merupakan kata bahasa arab berupa isim masdar (kata benda) dari verba ta'allama (تَعَلَّمَ) berdasarkan kamus bahasa arab Mahmud Yunus ditulis تَعلُّم (ta'allum) yang berarti 'belajar'. Kata belajar merupakan kosakata yang termasuk ke dalam kata kerja (verba). Kata kerja (verba) berarti kata yang memiliki makna yang berkaitan langsung dengan perbuatan, keadaan, proses, dan perbuatan pasif. Kata belajar termasuk ke dalam kata kerja (verba) sebab kata belajar menunjukkan sebuah perbuatan, artinya sedang melakukan kegiatan belajar. Kata ta'allum mengalami interferensi yaitu interferensi leksikal kelas kata verba. Interferensi leksikal kelas kata verba adalah interferensi yang terjadi karena adanya pengacauan kata kerja (verba) bahasa Indonesia oleh bahasa Arab baik dalam bentuk dasar maupun bentuk turunannya.

Contoh kutipan yang terdapat interferensi bahasa arab ta'allum sebagai berikut :

Dedi : Ya biasa lah, ane masih sibuk ta'allum aja nih buat imtihan

Kalimat tersebut merupakan struktur kalimat bahasa Indonesia yang mengalami interferensi leksikal bahasa Arab karena terdapat unsur kosakata bahasa Arab yang masuk kedalam struktur kalimat tersebut. Kosakata yang mengalami interferensi adalah kata ta'allum yang seharusnya dalam bahasa Indonesia sudah ada padanan katanya yaitu belajar. Kata ta'allum sering digunakan oleh kebanyakan santri untuk menyebut kata belajar dalam kegiatan percakapan sehari-hari sehingga faktor kebiasaan pun menyebabkan hal tersebut terbawa dalam percakapan sehari-hari.

5. Interferensi Kata Imtihan 
Kata imtihan merupakan kata bahasa arab berupa isim masdar (kata benda) dari kata dasar verba imtahana ( إِنْحَنَ ), jika ditulis dalam bahasa arab adalah إِمْنِحَان dibaca imtihan yang berarti 'ujian'. Kata ujian merupakan kosakata yang termasuk ke dalam kata kerja (verba). Kata kerja (verba) berarti kata yang memiliki makna yang berkaitan langsung dengan perbuatan, keadaan, proses, dan perbuatan pasif. Kata ujian termasuk ke dalam kata kerja (verba) sebab kata ujian menunjukkan sebuah perbuatan, artinya sedang atau akan melakukan kegiatan ujian. Kata imtihan mengalami interferensi, yaitu interferensi leksikal kelas kata verba. Interferensi leksikal kelas kata verba adalah interferensi yang terjadi karena adanya pengacauan kata kerja (verba) bahasa Indonesia oleh bahasa Arab baik dalam bentuk dasar maupun bentuk turunannya.

Contoh kutipan yang terdapat interferensi bahasa arab imtihan sebagai berikut :

Dedi : Ya biasa lah, ane masih sibuk ta'allum aja nih buat imtihan

Kalimat tersebut merupakan struktur kalimat bahasa Indonesia yang mengalami interferensi leksikal bahasa Arab karena terdapat unsur kosakata bahasa Arab yang masuk kedalam struktur kalimat tersebut. Kosakata yang mengalami interferensi adalah kata imtihan yang seharusnya dalam bahasa Indonesia sudah ada padanan katanya yaitu ujian. Kata imtihan sering digunakan oleh kebanyakan santri untuk menyebut kata ujian dalam kegiatan percakapan sehari-hari sehingga faktor kebiasaan pun menyebabkan hal tersebut terbawa dalam percakapan sehari-hari.

\section{Interferensi Kata Qalil}

Kata qalil merupakan kata bahasa arab berupa isim (kata benda) dari

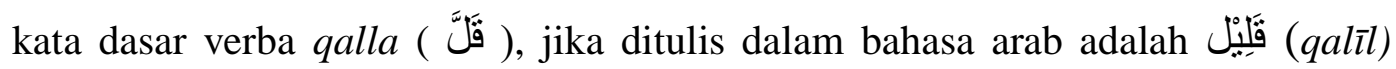
yang berarti 'sedikit'. Kata sedikit merupakan kosakata yang termasuk ke dalam kata sifat (adjektifa). Kata sifat (adjektifa) berarti kata yang memberikan sifat khusus, watak, atau keadaan yang disebutkan terlebih dahulu . Kata sedikit termasuk ke dalam kata sifat (adjektifa) sebab kata sedikit menunjukkan sesuatu dengan jumlah sedikit. Kata qalīl mengalami interferensi, yaitu interferensi leksikal kelas kata adjektifa. Interferensi leksikal kelas kata adjektifa adalah 
interferensi yang terjadi karena adanya pengacauan kata sifat (adjektifa) bahasa Indonesia oleh bahasa Arab baik dalam bentuk dasar maupun bentuk turunannya.

Contoh kutipan yang terdapat interferensi bahasa arab qalīl sebagai berikut :

Dedi : Imtihan matematika $\mathrm{Bi}$, baru qolīl lagi ta'allumnya

Kalimat tersebut merupakan struktur kalimat bahasa Indonesia yang mengalami interferensi leksikal bahasa Arab karena terdapat unsur kosakata bahasa Arab yang masuk kedalam struktur kalimat tersebut. Kosakata yang mengalami interferensi adalah kata qalìl yang seharusnya dalam bahasa Indonesia sudah ada padanan katanya yaitu sedikit. Kata qalīl sering digunakan oleh santri untuk menyebut kata sedikit dalam kegiatan percakapan sehari-hari sehingga faktor kebiasaan pun menyebabkan hal tersebut terbawa dalam percakapan seharihari.

\section{Interferensi Kata Yasir}

Kata yasìr merupakan kata bahasa arab berupa isim (kata benda) dari kata dasar verba yasara ( يَسَرَ), jika ditulis dalam bahasa arab adalah يَبِيْرِ (yasir) yang berarti mudah. Kata mudah merupakan kosakata yang termasuk ke dalam kata sifat (adjektifa). Kata sifat (adjektifa) berarti kata yang memberikan sifat khusus, watak, atau keadaan yang disebutkan terlebih dahulu . Kata mudah termasuk ke dalam kata sifat (adjektifa) sebab kata mudah menunjukkan sesuatu yang mudah. kata yasīr mengalami interferensi yaitu interferensi leksikal kelas kata adjektifa. Interferensi leksikal kelas kata adjektifa adalah interferensi yang terjadi karena adanya pengacauan kata sifat (adjektifa) bahasa Indonesia oleh bahasa Arab baik dalam bentuk dasar maupun bentuk turunannya.

Contoh kutipan yang terdapat interferensi bahasa arab yasīr sebagai berikut :

Habi : Yasir itu mah, kalau ta'allum pasti juga bisa ente

Kalimat tersebut merupakan struktur kalimat bahasa Indonesia yang mengalami interferensi leksikal bahasa Arab karena terdapat unsur kosakata bahasa Arab yang masuk kedalam struktur kalimat tersebut. Kosakata yang mengalami interferensi adalah kata yasìr yang seharusnya dalam bahasa Indonesia sudah ada padanan katanya yaitu mudah. Kata yasìr sering digunakan oleh 
kebanyakan santri untuk menyebut kata mudah dalam kegiatan percakapan seharihari sehingga faktor kebiasaan pun menyebabkan hal tersebut terbawa dalam percakapan sehari-hari.

\section{Interferensi Kata Naqes}

Kata naqes merupakan kata bahasa arab berupa isim (kata benda) dari kata dasar verba naqosho ( نَقَّقصَ ), jika ditulis dalam bahasa arab adalah (naqish) yang berarti kurang. Kata kurang merupakan kosakata yang termasuk ke dalam kata sifat (adjektifa). Kata sifat (adjektifa) berarti kata yang memberikan sifat khusus, watak, atau keadaan yang disebutkan terlebih dahulu . Kata kurang termasuk ke dalam kata sifat (adjektifa) sebab kata kurang menunjukkan sesuatu yang kurang. Kata naqish mengalami interferensi yaitu interferensi leksikal kelas kata adjektifa. Interferensi leksikal kelas kata adjektifa adalah interferensi yang terjadi karena adanya pengacauan kata sifat (adjektifa) bahasa Indonesia oleh bahasa Arab baik dalam bentuk dasar maupun bentuk turunannya.

Contoh kutipan yang terdapat interferensi bahasa arab naqes sebagai berikut :

Dedi : Iya juga sih, tapi kalau matematika ane naqes pemahamannya

Kalimat tersebut merupakan struktur kalimat bahasa Indonesia yang mengalami interferensi leksikal bahasa Arab karena terdapat unsur kosakata bahasa Arab yang masuk kedalam struktur kalimat tersebut. Kosakata yang mengalami interferensi adalah kata naqes yang seharusnya dalam bahasa Indonesia sudah ada padanan katanya yaitu kurang. Kata naqes sering digunakan oleh kebanyakan santri untuk menyebut kata kurang dalam kegiatan percakapan sehari-hari sehingga faktor kebiasaan pun menyebabkan hal tersebut terbawa dalam percakapan sehari-hari.

\section{Interferensi Kata Jarrib}

Kata jarrib merupakan kata bahasa arab dari kata dasar verba jarroba ( ) جَرَّبَ yang berarti mencoba. Kata mencoba merupakan kosakata yang termasuk ke dalam kata kerja (verba). Kata kerja (verba) berarti kata yang memiliki makna yang berkaitan langsung dengan perbuatan, keadaan, proses, dan perbuatan pasif. Kata mencoba termasuk ke dalam kata kerja (verba) sebab kata mencoba 
menunjukkan sebuah perbuatan, artinya sedang atau akan mencoba. Kata jarrib mengalami interferensi yaitu interferensi leksikal kelas kata verba. Interferensi leksikal kelas kata verba adalah interferensi yang terjadi karena adanya pengacauan kata kerja (verba) bahasa Indonesia oleh bahasa Arab baik dalam bentuk dasar maupun bentuk turunannya.

Contoh kutipan yang terdapat interferensi bahasa arab jarrib sebagai berikut :

Habi : Ya jarrib dulu lah baru takallam kaya gitu, belum apa-apa dah nyerah aja ente

Kalimat tersebut merupakan struktur kalimat bahasa Indonesia yang mengalami interferensi leksikal bahasa Arab karena terdapat unsur kosakata bahasa Arab yang masuk kedalam struktur kalimat tersebut. Kosakata yang mengalami interferensi adalah kata jarrib yang seharusnya dalam bahasa Indonesia sudah ada padanan katanya yaitu mencoba. Kata jarrib sering digunakan oleh kebanyakan santri untuk menyebut kata mencoba dalam kegiatan percakapan sehari-hari sehingga faktor kebiasaan pun menyebabkan hal tersebut terbawa dalam percakapan sehari-hari.

\section{Interferensi Kata Takallam}

Kata takallam merupakan kata bahasa arab, dalam kamus bahasa arab Mahmud Yunus ditulis تَكَلَّم (takallama) yang berarti berbicara. Kata berbicara merupakan kosakata yang termasuk ke dalam kata kerja (verba). Kata kerja (verba) berarti kata yang memiliki makna yang berkaitan langsung dengan perbuatan, keadaan, proses, dan perbuatan pasif. Kata berbicara termasuk ke dalam kata kerja (verba) sebab kata berbicara menunjukkan sebuah perbuatan, artinya sedang atau akan berbicara. Kata takallam mengalami interferensi yaitu interferensi leksikal kelas kata verba. Interferensi leksikal kelas kata verba adalah interferensi yang terjadi karena adanya pengacauan kata kerja (verba) bahasa Indonesia oleh bahasa Arab baik dalam bentuk dasar maupun bentuk turunannya.

Contoh kutipan yang terdapat interferensi bahasa arab jarrib adalah sebagai berikut :

Habi : Ya jarrib dulu lah baru takallam kaya gitu, belum apa-apa dah nyerah aja ente 
Kalimat tersebut merupakan struktur kalimat bahasa Indonesia yang mengalami interferensi leksikal bahasa Arab karena terdapat unsur kosakata bahasa Arab yang masuk kedalam struktur kalimat tersebut. Kosakata yang mengalami interferensi adalah kata takallam yang seharusnya dalam bahasa Indonesia sudah ada padanan katanya yaitu berbicara. Kata takallam sering digunakan oleh kebanyakan santri untuk menyebut kata berbicara dalam kegiatan percakapan sehari-hari sehingga faktor kebiasaan pun menyebabkan hal tersebut terbawa dalam percakapan sehari-hari.

\section{Interferensi Kata Fashel}

Kata fashel merupakan kata bahasa arab, dalam kamus bahasa arab Mahmud Yunus ditulis فَصْنٌ (fashlun) yang berarti kelas. Kata kelas merupakan kosakata yang termasuk ke dalam kata benda (nomina). Kata benda (nomina) berarti jenis kata yang mengacu terhadap benda, manusia, binatang, dan pengertian. Kata kelas termasuk ke dalam kata benda (nomina) sebab kata kelas menunjukkan suatu tempat yang digunakan untuk belajar. Kata fashel mengalami interferensi yaitu interferensi leksikal kelas kata nomina. Interferensi leksikal kelas kata nomina adalah interferensi yang terjadi karena adanya pengacauan kata benda (nomina) bahasa Indonesia oleh bahasa Arab baik dalam bentuk dasar maupun bentuk turunannya.

Contoh kutipan yang terdapat interferensi bahasa arab fashel sebagai berikut :

Dedi : Siapa guru matematika di fashel ente?

Kalimat tersebut merupakan struktur kalimat bahasa Indonesia yang mengalami interferensi leksikal bahasa Arab karena terdapat unsur kosakata bahasa Arab yang masuk kedalam struktur kalimat tersebut. Kosakata yang mengalami interferensi adalah kata fashel yang seharusnya dalam bahasa Indonesia sudah ada padanan katanya yaitu kelas. Kata fashel sering digunakan oleh kebanyakan santri untuk menyebut kata kelas dalam kegiatan percakapan sehari-hari sehingga faktor kebiasaan pun menyebabkan hal tersebut terbawa dalam percakapan sehari-hari.

\section{Interferensi Kata Mataa}


Kata mataa merupakan kata bahasa arab yang menunjukan kata tanya untuk waktu. Kata mataa sebagaimana dalam kamus bahasa arab Mahmud Yunus ditulis مَنَّى (mataa) yang berarti kapan. Kata kapan merupakan kosakata yang termasuk ke dalam kata ganti penanya (pronomina penanya). Kata ganti penanya (pronomina penanya) memiliki makna menggantikan sesuatu yang ditanyakan. Kata kapan termasuk ke dalam kata ganti (pronomina) sebab kata kapan menggantikan nomina yang ada yaitu waktu. Kata mataa mengalami interferensi yaitu interferensi leksikal kelas kata pronomina. Interferensi leksikal kelas kata pronomina adalah interferensi yang terjadi karena adanya pengacauan kata ganti (pronomina) bahasa Indonesia oleh bahasa Arab baik dalam bentuk dasar maupun bentuk turunannya.

Contoh kutipan yang terdapat interferensi bahasa arab mata sebagai berikut :

Dedi : Hmmmm beliau, mata imtihannya Bi

Kalimat tersebut merupakan struktur kalimat bahasa Indonesia yang mengalami interferensi leksikal bahasa Arab karena terdapat unsur kosakata bahasa Arab yang masuk kedalam struktur kalimat tersebut. Kosakata yang mengalami interferensi adalah kata mata yang seharusnya dalam bahasa Indonesia sudah ada padanan katanya yaitu kapan. Kata mata sering dipergunakan oleh kebanyakan santri terlebih bagi pesantren yang berbasis modern dalam menyebut kata kapan dalam kegiatan percakapan sehari-hari sehingga faktor kebiasaan pun menyebabkan hal tersebut terbawa dalam percakapan sehari-hari.

\section{Interferensi Kata Yaum}

Kata yaum sebagaimana dalam kamus bahasa arab Mahmud Yunus ditulis يَوْمُ (yaumun) yang berarti hari. Kata hari merupakan kosakata yang termasuk ke dalam kata benda (nomina). Kata benda (nomina) berarti jenis kata yang mengacu terhadap benda, manusia, binatang, dan pengertian. Kata hari termasuk ke dalam kata benda (nomina) sebab kata hari berdasarkan kriteria nomina memiliki ciri tidak dapat didahului oleh adverbial negasi tidak. Sehingga tidak bisa kita ucapkan tidak hari. Kata yaum mengalami interferensi yaitu interferensi leksikal kelas kata nomina. Interferensi leksikal kelas kata nomina adalah interferensi yang terjadi karena adanya pengacauan kata benda (nomina) 
bahasa Indonesia oleh bahasa Arab baik dalam bentuk dasar maupun bentuk turunannya.

Contoh kutipan yang terdapat interferensi bahasa arab yaum sebagai berikut :

Habi : Yaum kamis ghodan

Kalimat tersebut merupakan struktur kalimat bahasa Indonesia yang mengalami interferensi leksikal bahasa Arab karena terdapat unsur kosakata bahasa Arab yang masuk kedalam struktur kalimat tersebut. Kosakata yang mengalami interferensi adalah kata yaum yang seharusnya dalam bahasa Indonesia sudah ada padanan katanya yaitu hari. Kata yaum sering digunakan oleh santri untuk menyebut kata hari dalam kegiatan percakapan sehari-hari sehingga faktor kebiasaan pun menyebabkan hal tersebut terbawa dalam percakapan seharihari.

\section{Interferensi Kata Ghodan}

Kata ghodan dalam kamus bahasa arab Mahmud Yunus ditulis غَدَآ (ghodan) yang berarti besok. Kata besok merupakan kosakata yang termasuk ke dalam kata keterangan (Adverbia). Kata keterangan (Adverbia) berarti kata yang menerangkan kata kerja, kata sifat, dan jenis kata yang lainnya. Kata besok termasuk ke dalam kata keterangan (adverbia) sebab kata besok menerangkan bahwa perbuatannya akan dilakukan esok hari. Kata ghodan mengalami interferensi yaitu interferensi leksikal kelas kata adverbia. Interferensi leksikal kelas kata adverbia adalah interferensi yang terjadi karena adanya pengacauan kata keterangan (adverbia) bahasa Indonesia oleh bahasa Arab baik dalam bentuk dasar maupun bentuk turunannya.

Contoh kutipan yang terdapat interferensi bahasa arab ghodan sebagai berikut :

Habi : hari kamis ghodan

Kalimat tersebut merupakan struktur kalimat bahasa Indonesia yang mengalami interferensi leksikal bahasa Arab karena terdapat unsur kosakata bahasa Arab yang masuk kedalam struktur kalimat tersebut. Kosakata yang mengalami interferensi adalah kata ghodan yang seharusnya dalam bahasa Indonesia sudah ada padanan katanya yaitu besok. Kata ghodan sering digunakan 
oleh santri untuk menyebut kata besok dalam kegiatan percakapan sehari-hari sehingga faktor kebiasaan pun menyebabkan hal tersebut terbawa dalam percakapan sehari-hari.

\section{Interferensi Kata Akhof}

Kata akhof merupakan kata bahasa arab, dalam kamus bahasa arab Mahmud Yunus ditulis آخَافت (akhofu) yang berarti takut. Kata takut merupakan kosakata yang termasuk ke dalam kata sifat (adjektifa). Kata sifat (adjektifa) berarti kata yang memberikan sifat khusus, watak, atau keadaan yang disebutkan terlebih dahulu . Kata takut termasuk ke dalam kata sifat (adjektifa) sebab kata takut menunjukkan seseorang yang memiliki sifat takut. Kata akhofu mengalami interferensi yaitu interferensi leksikal kelas kata adjektifa. Interferensi leksikal kelas kata adjektifa adalah interferensi yang terjadi karena adanya pengacauan kata sifat (adjektifa) bahasa Indonesia oleh bahasa Arab baik dalam bentuk dasar maupun bentuk turunannya.

Contoh kutipan yang terdapat interferensi bahasa arab akhof sebagai berikut :

Habi : Iya makanya ane akhof gak bisa ngerjainnya

Kalimat tersebut merupakan struktur kalimat bahasa Indonesia yang mengalami interferensi leksikal bahasa Arab karena terdapat unsur kosakata bahasa Arab yang masuk kedalam struktur kalimat tersebut. Kosakata yang mengalami interferensi adalah kata akhof yang seharusnya dalam bahasa Indonesia sudah ada padanan katanya yaitu takut. Kata akhof sering digunakan oleh kebanyakan santri untuk menyebut kata takut dalam kegiatan percakapan sehari-hari sehingga faktor kebiasaan pun menyebabkan hal tersebut terbawa dalam percakapan sehari-hari.

Tabel 4.3 Rekapitulasi Interferensi Leksikal

\begin{tabular}{|c|c|c|c|c|c|c|c|c|c|}
\hline \multirow{2}{*}{ NO. } & Nama & \multicolumn{6}{|c|}{ Interferensi Leksikal } & \multirow{2}{*}{ Jumlah } \\
\cline { 3 - 11 } & & n & v & adj & pro & num & adv & kt & \\
\hline 1. & Wawancara 1 & 1 & 6 & 5 & 3 & 0 & 1 & 2 & 18 \\
\hline 2. & Wawancara 2 & 5 & 4 & 4 & 1 & 1 & 1 & 1 & 17 \\
\hline 3. & Wawancara 3 & 1 & 3 & 2 & 0 & 0 & 0 & 0 & 6 \\
\hline 4. & Wawancara 4 & 2 & 2 & 2 & 0 & 0 & 1 & 2 & 9 \\
\hline 5 & Wawancara 5 & 0 & 0 & 3 & 0 & 2 & 2 & 0 & 7 \\
\hline & Jumlah & 9 & 15 & 16 & 4 & 3 & 5 & 5 & 57 \\
\hline
\end{tabular}




\section{Keterangan :}

$$
\begin{aligned}
& \mathrm{N}: \text { Nomina/ kata benda } \\
& \mathrm{V} \quad \text { : Verba/ kata kerja } \\
& \text { Adj }: \text { Adjektiva/ kata sifat } \\
& \text { Pro : Pronominal/ kata ganti } \\
& \text { Num : Numeralia/ kata bilangan } \\
& \text { Adv : Adverbia/ kata keterangan } \\
& \text { Kt }: \text { Kata tugas }
\end{aligned}
$$

\section{E. Simpulan}

Berdasarkan hasil dari temuan dan analisis dapat disimpulkan bahwa dalam percakapan santri Pondok Pesantren Riyadhul Huda Kota Tangerang terdapat interferensi leksikal yaitu berupa interferensi leksikal pada kelas kata benda (nomina), kelas kata kerja (verba), kelas kata sifat (adjektiva), kelas kata ganti (pronominal), kelas kata keterangan (adverbia), dan kelas kata tugas, dan kelas kata bilangan (numeralia). Total interferensi leksikal pada percakapan yaitu 57 kata. Interferensi terbanyak pada kelas kata sifat (adjektifa) yaitu 16 kata.

Interferensi kelas kata kerja (verba) sebanyak 15 kata, interferensi kelas kata keterangan (adverb) sebanyak 5 kata, interferensi kelas kata benda (nomina) sebanyak 9 kata, interferensi kelas kata tugas sebanyak 5 kata, interferensi kelas kata bilangan (numeralia) sebanyak 3 kata dan interferensi kelas kata ganti (pronominal) sebanyak 4 kata. Hal ini disebabkan karena terkait aturan dalam pondok pesantren yang mewajibkan para santri di pondok pesantren Riyadhul Huda untuk menggunakan bahasa arab dalam percakapan sehari-hari sehingga kebiasaan tersebut tanpa disadari masuk ke dalam percakapan para santri tanpa melihat tempat dan siapa yang diajak bicara.

\section{F. Daftar Pustaka}

Aslinda dan Leni Syafyahya. 2014. Pengantar Sosiolinguistik. Bandung : Refika Aditama.

Chaer, Abdul dan Leonie Agustina. 2004. Sosiolinguistik: Perkenalan Awal. Jakarta : Rineka Cipta.

Mulyono, Iyo. 2016. Bahasa Indonesia Serba-Serbi Problematik Penggunaannya. Bandung : Yrama Widya. 